\title{
Sex-Related Seasonal Differences in the Foraging Strategy of the Kentish Plover
}

Author(s): MacArena Castro, Jose A. Masero, Alejandro Pérez-Hurtado, Juan A. Amat, and Cesar Megina Source: The Condor, 111(4):624-632. 2009.

Published By: Cooper Ornithological Society

URL: http://www.bioone.org/doi/full/10.1525/cond.2009.080062

BioOne (www.bioone.org) is a nonprofit, online aggregation of core research in the biological, ecological, and environmental sciences. BioOne provides a sustainable online platform for over 170 journals and books published by nonprofit societies, associations, museums, institutions, and presses.

Your use of this PDF, the BioOne Web site, and all posted and associated content indicates your acceptance of BioOne's Terms of Use, available at www.bioone.org/page/terms of use.

Usage of BioOne content is strictly limited to personal, educational, and non-commercial use. Commercial inquiries or rights and permissions requests should be directed to the individual publisher as copyright holder. 


\title{
SEX-RELATED SEASONAL DIFFERENCES IN THE FORAGING STRATEGY OF THE KENTISH PLOVER
}

\author{
Macarena Castro ${ }^{1,4}$, Jose A. Masero ${ }^{2}$, Alejandro Pérez-Hurtado ${ }^{1}$, Juan A. Amat 3 , \\ ANd CESAR MEgina ${ }^{1}$ \\ ${ }^{1}$ Departamento de Biología Animal, Facultad de Ciencias del Mar y Ambientales, Universidad de Cádiz, \\ E-11510 Puerto Real, Spain \\ ${ }^{2}$ Grupo de Investigación en Conservación, Área de Zoología, Facultad de Ciencias, Universidad de Extremadura, \\ Avenida de Elvas s/n, E-06071 Badajoz, Spain \\ ${ }^{3}$ Estación Biológica de Doñana, Consejo Superior de Investigaciones Científicas, \\ Apdo 1056, E-41080 Sevilla, Spain
}

Abstract. In species of birds with biparental care, each sex may have its own energy requirements and/or schedule for feeding, possibly leading the sexes to differ in foraging strategy. In estuaries, shorebirds such as the Kentish Plover (Charadrius alexandrinus alexandrinus) may forage on intertidal mudflats and in adjacent supratidal habitats during winter as well as during the breeding season. In this study, we analyzed the diet, use of foraging habitat, food-intake rate (biomass ingested per unit time), and time allocated to foraging by male and female Kentish Plovers at both seasons in an estuary near Cádiz, Spain, where intertidal mudflats and adjacent salt works are the main habitats for foraging. The plovers' main prey was the ragworm (Nereis diversicolor), an intertidal polychaete that supplied more than $80 \%$ of the biomass consumed at each season. During the breeding season, both sexes increased their intake rate and decreased their daylight foraging time. By increasing the diurnal intake rate during the breeding season, the birds minimized their time spent foraging on the intertidal mudflats, allowing them to maximize the time for activities associated with breeding in the adjacent salt works. Therefore, the plovers solved the conflict between foraging on the mudflats and breeding in the salt works by shortening the foraging time on the mudflats, minimizing time away from the nesting areas. The sexes differed in the daylight time allocated to foraging, with females spending $2 \mathrm{hr}$ less on foraging and concentrating their feeding activity into the central hours of low tide.

Key words: Charadrius alexandrinus, foraging, habitat use, intake rate, saltworks, sex difference, Kentish Plover, shorebirds.

\section{Diferencias Estacionales Relacionadas con el Sexo en la Estrategia de Alimentación de Charadrius alexandrinus}

Resumen. En especies de aves con cuidado biparental, cada sexo puede tener sus propios requerimientos de energía y/o esquema de tiempo para la alimentación, lo cual podría conducir a diferencias en las estrategias de alimentación entre ambos sexos. En los estuarios, las especies de playeros como Charadrius alexandrinus pueden forrajear en fangos intermareales y en hábitats supramareales adyacentes tanto durante el invierno así como durante la época reproductiva. Aquí, analizamos la dieta, el uso de hábitat de forrajeo, la tasa de ingestión (biomasa ingerida por unidad de tiempo) y el tiempo dedicado al forrajeo por el macho y la hembra de C. alexandrinus durante ambas temporadas en una zona estuarina donde los fangos intermareales y las salinas adyacentes son las principales áreas de alimentación. La principal presa para C. alexandrinus fue un poliqueto (Nereis diversicolor), una presa intermareal que suplió más del $80 \%$ de la biomasa consumida en cada estación. Ambos sexos incrementaron sus tasas de alimentación durante la época reproductiva, y disminuyeron sus tiempos diurnos de forrajeo. Por el incremento de la tasa de ingestión durante la época reproductiva, las aves minimizaron el tiempo que pasaron en los fangos intermareales, lo que les permitió maximizar el tiempo dedicado a las actividades de reproducción en las salinas adyacentes. Por lo tanto, el conflicto entre alimentarse en los fangos versus el desarrollo de las actividades de reproducción (en las salinas), fue resuelto acortando el tiempo en los fangos, minimizando el tiempo fuera de las zonas de nidada. Hubo diferencias relacionadas con el sexo en el tiempo diurno dedicado al forrajeo: las hembras dedicaron dos horas menos a la alimentación y concentraron su actividad de alimentación en las horas centrales de la marea baja.

Manuscript received 23 October 2008; accepted 4 August 2009.

${ }^{4}$ Current address: Centro de Investigación en Ecosistemas de la Patagonia, Bilbao 449, Coyhaique, Chile. E-mail: macarena.castro@ciep.cl

The Condor, Vol. 111, Number 4, pages 624-632. ISSN 0010-5422, electronic ISSN 1938-5422. (๑) 2009 by The Cooper Ornithological Society. All rights reserved. Please direct all requests for permission to photocopy or reproduce article content through the University of California Press's Rights and Permissions website, http://www.ucpressjournals.com/ reprintInfo.asp. DOI: 10.1525/cond.2009.080062 


\section{INTRODUCTION}

Different behaviors require time and/or energy and cannot be carried out simultaneously. This conflict may lead to tradeoffs among different activities. For instance, feeding is not compatible with any other energy-demanding activity (Cuthill and Houston 1997). Such trade-offs are likely to be more apparent during the breeding season, when resource allocation can affect fecundity, survival, and time devoted to reproduction strongly (Sibly and Calow 1986, Williams 1996). In many species of birds, successful breeding requires biparental care. In these species, both parents spend a substantial fraction of each day on the nest, reducing the time available for foraging. During incubation, extended absences from the nest may result in changes in egg temperatures that can affect embryo development negatively (Webb 1987, Amat and Masero 2007) as well as increase the time of exposure to predators (Tulp and Schekkerman 2006). Therefore, the two sexes should not forage at the same time so that the nest can be almost continuously attended by an adult.

Many migratory shorebirds (Charadrii) rely on intertidal habitats for foraging during both the winter and the breeding season. Owing to their small size and their high mass-specific metabolic rates, shorebirds have a limited capacity to store energy before the onset of breeding and are therefore obliged to feed during incubation (Tulp and Schekkerman 2006). The intertidal habitat is available for only part of each day, and during the breeding season males and females must alternate leaving the nest for the intertidal areas to satisfy their requirements for both food and nest attendance. Nonetheless, seasonal differences in shorebirds' foraging behavior have been studied only infrequently (Durrell 2001).

The Kentish/Snowy Plover (Charadrius alexandrinus) is a migratory shorebird with biparental incubation, females incubating by day, males by night (Warriner et al. 1986, Fraga and Amat 1996). In estuaries, it can feed in intertidal mudflats as well as in adjacent supratidal habitats (Piersma 1996, Masero et al. 2000). In this study we compared the foraging strategies of male and female Kentish Plovers in the winter and breeding season in an estuary in which intertidal mudflats and adjacent saltworks (salinas or saltpans) are the main foraging grounds (Masero et al. 2000, Castro 2001). Because the Kentish Plover can nest only in the supratidal habitat, we expected an increase during the breeding season in the use of saltworks for foraging as a result of, for example, territorial behavior. The foraging behavior of typical plovers is highly stereotyped, and short-billed species such as the Kentish Plover all forage visually in a run-stop-search manner (Masero et al. 2007). The energetic demands of breeding Kentish Plovers may differ by sex, explaining differences in foraging patterns. However, Amat et al. (2000) found no changes in body mass during incubation and early chick rearing of either males or females, and neither did they find sex-related differences in the energetic costs of incubation. Nevertheless, different roles during reproduction may still lead to differences between the sexes in patterns of foraging. Because females incubate by day and males by night, we expected sexual differences in patterns of habitat use, diet, intake rate (biomass ingested per unit time), and time allocated to feeding during the breeding season.

In both Europe and the Americas Charadrius alexandrinus is suffering sharp population declines (Brown et al. 2000, Delany and Scott 2006), and many initiatives to halt this decline have involved habitat-restoration plans (Laferty et al. 2006). Because populations of migratory birds can be influenced by events during winter, migration, or breeding (Sillet et al. 2000), effective shorebird conservation requires an understanding of when and how populations are limited and regulated (Skagen 2006). In this context, intake rate is used by modelers to estimate energy budgets, predator-prey interactions, the quality of feeding grounds, and other factors that may affect fitness, such as the risk of being taken by a predator, and food-related reproductive success (Goss-Custard et al. 2006). Accordingly, our results for seasonal variation in intake rate may bear significantly on the success of conservation plans for C. alexandrinus.

\section{METHODS}

\section{STUDY SITE}

We chose an industrial saltworks of 400 ha in the north of Cádiz Bay Natural Park $\left(36^{\circ} 23^{\prime} \mathrm{N}, 6^{\circ} 8^{\prime} \mathrm{W}\right)$, southwestern Spain, as the study area, together with $20-30$ ha of adjacent intertidal mudflats at a distance of 50-800 m (Fig. 1). About 400 Kentish Plovers regularly winter in this saltworks, while during breeding there are about 120 individuals (Masero et al. 2000, this study). The intertidal mudflats are exposed (i.e., available for shorebirds) for 7-9 hr daily (semidiurnal tides).

The study area (saltworks and adjacent intertidal mudflats) is surrounded by anthropogenic habitats unsuitable for shorebirds, thus constituting an isolated wetland in the north of Cádiz Bay (Fig. 1). Overall, the study area functions as a closed system for overwintering shorebirds. Small shorebirds such as the Kentish Plover rest at high tide in the saltworks and forage in the adjacent intertidal mudflats at low tide, with no apparent movements between this isolated wetland and the rest of the bay throughout the winter (Hortas 1997, Masero et.al. 2000, Masero et al. 2001). At Cádiz Bay, Kentish Plovers have been banded since 1994 with both metal and color bands (e.g., Pérez-Hurtado et al. 1994, Torija 2005). During our study, $36 \%$ of the Kentish Plovers breeding in the study area were color-banded (pers. obs.), and we noted that at least $44 \%$ of these color-banded Kentish Plovers breeding in the saltworks had wintered in the same area previously (pers. obs.).

Sex recognition was possible in most cases by plumage dimorphism (males have a black bar on the front of their foreheads, females do not; see Hayman et al. 1995 for plumage descriptions). We could distinguish the sexes $\sim 86 \%$ of the time even in winter when the plumage is more cryptic (Table 1). 


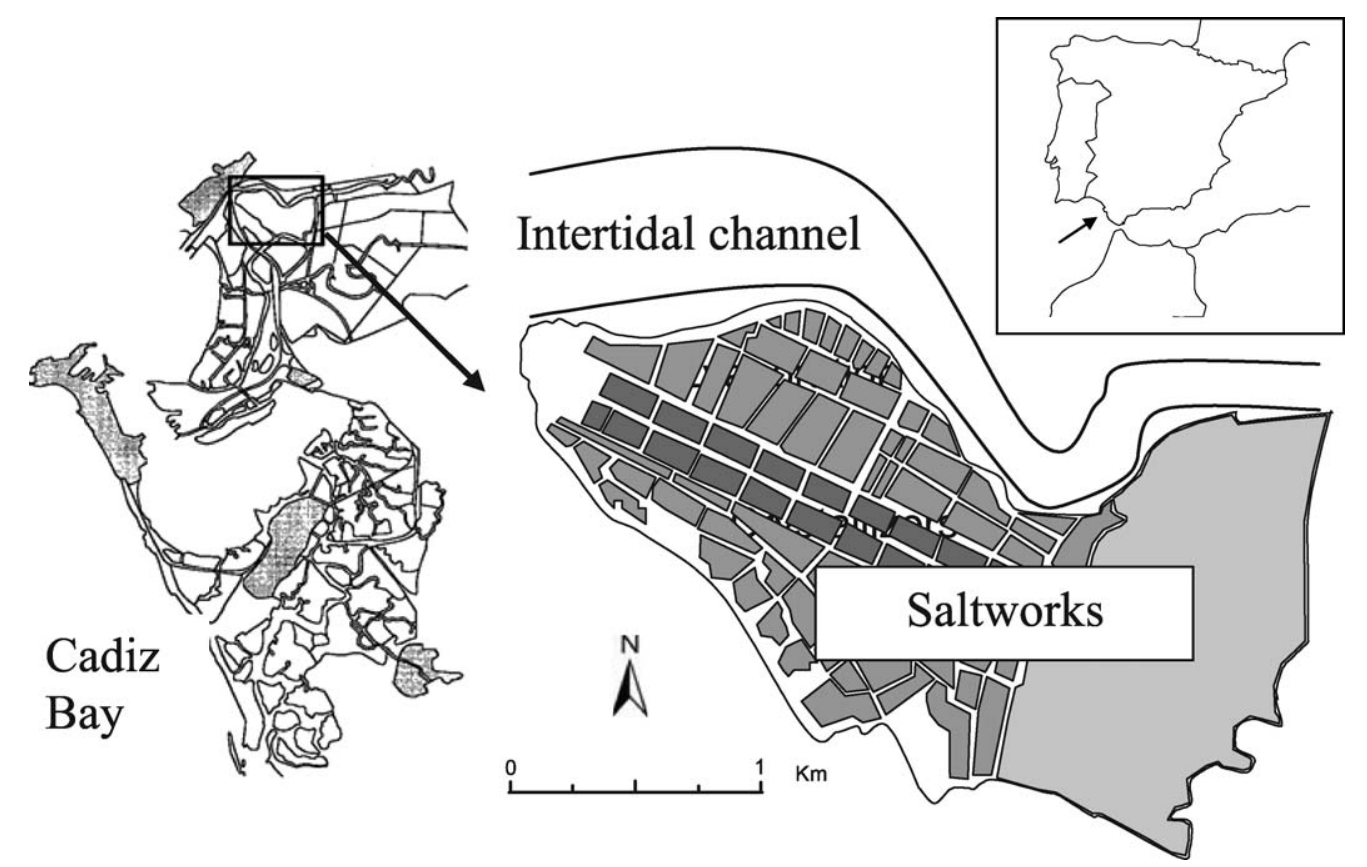

FIGURE 1. Study area, showing intertidal mudflats (intertidal channel) and adjacent saltworks (supratidal area). The study area constitutes an isolated wetland in the north of Cádiz Bay, southwestern Spain.

\section{USE OF FORAGING HABITAT}

Our field observations extended from December 1996 to June 1997. The number of male and female Kentish Plovers foraging and resting (including preening) in the saltworks was recorded once per week (except one week in winter in which weather conditions made it impossible), at both high and low tides, in December and January (winter) and in May and June (breeding season). The maximum numbers of active nests and adult birds recorded in the saltworks during this breeding season were 57 and 113, respectively. During the observations of foraging in the saltworks at high tide, we noted that all these Kentish Plovers were engaged in typical breeding behaviors such as nest attendance, distraction displays, or territorial fights (on average, $>80 \%$ of the pairs were involved in nest attendance and less than $10 \%$ were caring for chicks; pers. obs.). Accordingly, we assumed that all adult Kentish Plovers recorded during the foraging studies in the study area in May and June were breeding birds (juveniles can be distinguished by the narrow buff fringes on their coverts and scapulars; Hayman et al. 1995).

Diurnal activity. We assumed the count in the saltworks at high tide to be the total number of Kentish Plovers in the study area and the difference between the total counted in the saltworks at high and low tides to be the part of the population visiting the mudflats. We recorded activity of plovers on the intertidal mudflats at low tide on the day after the census in the

TABLE 1. Numbers of male and female Kentish Plovers recorded in the saltworks (high and low tide) and on the intertidal mudflats during winter and the breeding season. Mean foraging activity (percentage of birds foraging $\pm 1 \mathrm{SD}$ ) is given in parentheses.

\begin{tabular}{|c|c|c|c|}
\hline & \multicolumn{2}{|c|}{ Saltworks } & \multirow[b]{2}{*}{ Intertidal mudflats } \\
\hline & High tide & Low tide & \\
\hline \multicolumn{4}{|l|}{ Wintering } \\
\hline Females & $139(26.43 \pm 10.41)$ & $12(100)$ & $152(95.61 \pm 5.66)$ \\
\hline Males & $150(10.35 \pm 5.29)$ & $21(100)$ & $135(96.82 \pm 8.63)$ \\
\hline Sex unknown & $45(32.51 \pm 10.22)$ & $4(100)$ & $10(95.41 \pm 7.45)$ \\
\hline \multicolumn{4}{|l|}{ Breeding } \\
\hline Females & $48(19.38 \pm 1.03)$ & $28 \quad(3.6 \pm 2.42)$ & $15(52.3 \pm 36.19)$ \\
\hline Males & $65(25.22 \pm 6.04)$ & $38 \quad(7.89 \pm 3.64)$ & $20(74.76 \pm 34.62)$ \\
\hline Sex unknown & $4(40.03 \pm 5.82)$ & $4 \quad(15.22 \pm 4.04)$ & $1(100)$ \\
\hline
\end{tabular}


saltworks and under similar conditions. Kentish Plovers feeding and resting on the intertidal mudflats were counted every hour during low tide (7-9 hr). Foraging activity on the mudflats, expressed as the percentage of Kentish Plovers foraging, was calculated for each count, and the percentages were later averaged for the entire low-tide period (Zwarts et al. 1990).

Nocturnal activity. During the breeding season, we used a light intensifier (Canon; 6.5× magnification, light-intensifying factor $70000 \times$ ) to record the birds' number and activity at night, always at a distance of 10 to $50 \mathrm{~m}$ from the focal individuals. Every 14 days we carried out nocturnal counts in the same area as our diurnal counts but during the period between $2 \mathrm{hr}$ before and $2 \mathrm{hr}$ after low tide. Nocturnal foraging activity on intertidal mudflats was calculated by comparing the numbers of individuals feeding by night and by day at the same site (Zwarts et al. 1990). Night censuses in the saltworks were carried out in the same way as the daylight censuses. Light from a nearby village facilitated identification of birds and their foraging activity, although sexing individuals was not possible. For winter, data on nocturnal activity were derived from a study carried out at the same site the same year (Masero et al. 2000).

Foraging-time allocation. The daily time spent foraging was derived from the proportions of males and females foraging in each habitat (intertidal mudflats or saltworks) relative to their total numbers, number of minutes that habitat was available, and proportion time the plovers spent foraging. For this calculation, we considered the duration of the low-tide period in the saltworks the same as the period during which the intertidal mudflats were exposed; the rest, up to the completion of the tidal cycle, was considered to be high tide (Masero and Pérez-Hurtado 2001). We could not distinguish the plovers' sex at night, so we assumed the sex ratio of birds foraging at night was similar.

\section{DIET AND INTAKE RATE}

Prey identification and size. We randomly selected actively foraging individuals, $<30 \mathrm{~m}$ from the observer, and observed them for $1 \mathrm{~min}$ with a $20-60 \times$ zoom telescope. After $1 \mathrm{~min}$, a new focal individual at least $10 \mathrm{~m}$ from the previous individual was chosen to avoid pseudoreplication (Hurlbert 1984). In every sequence, we recorded the following data: bird's sex, feeding rate (successful pecks $\mathrm{min}^{-1}$ ), type and size of prey items captured, and time since low tide. In the saltworks, plovers foraged on small prey items available at high densities along the shore of the pans, and we assumed that a prey item was ingested every time the bird pecked (pers. obs.; see similar procedure in Masero and Perez-Hurtado 2001).

Prey size was estimated in relation to average bill length. At Cádiz Bay there were no significant differences between males and females in bill length $\left(t_{43}=0.37, P=0.72\right.$; unpublished data), so we used an average length of $16 \mathrm{~mm}(15.56 \pm$ $0.82 \mathrm{~mm} ; n=45$ individuals, both sexes combined). Visual observations were contrasted with analyses of fecal samples (32 feces in winter and 30 in the breeding period, collected in roosting areas or when feeding birds were observed excreting). Masero et al. (1999) and Castro (2001) provided information about the species composition, size distribution, and biomass of the prey available to shorebirds in the study area. According to those studies, on the mudflats the plover's potential prey were the polychaete ragworm Nereis diversicolor, the bivalves Cerstoderma edule and Scrobicularia plana, the gastropod Hydrobia ulvae, and the isopod Cyathura carinata, while in the saltworks they were the brine shrimp ( $A r-$ temia spp.), adults and larvae of the coleopteran Ochthebius spp., and larvae of the dipterans Chironomus salinarius and Ephydra spp. All these potential prey leave recognizable hard parts after passing through a plover's digestive tract (Castro 2001).

Following the method of Zwarts and Blomert (1992), we used the cumulative frequency distribution of prey sizes found in feces to correct visual estimates of prey sizes.

Biomass ingested. We converted the length of each prey item into biomass by the equations in Masero et al. (1999) and Masero and Perez-Hurtado (2001). We were not able to estimate accurately in the field the species and the length of polychaete worms shorter than half a plover's bill length (which corresponded to $12 \mathrm{~mm}$ after correction of the visual estimates; see above). For this size class of prey, we assumed as average biomass the average biomass of the polychaetes smaller than $12 \mathrm{~mm}$ available in the intertidal mud (data from Masero et al. 1999 and Castro 2001; see previous section).

Finally, we estimated intake rate ( $\mathrm{mg}$ of ash-free dry mass $\mathrm{sec}^{-1}$ ) by multiplying the number of each size class taken per minute by the ash-free dry mass of that size class.

There are no published data on seasonal variation in the condition of invertebrates in Cádiz Bay. Therefore, our estimates of intake rates during the breeding season may be considered conservative given that warmer temperatures may affect the availability and condition of invertebrates (Zwarts and Wanink 1993). Likely, if there are seasonal or sex-related differences in intake rate, they may be slightly higher than those we report.

\section{STATISTICAL ANALYSES}

We used a covariance analysis (ANCOVA) to explore sexrelated differences in the percentage of individuals using the mudflats and saltworks at each season. In this analysis, sex (male/female), season (winter/breeding), and site (mudflats/ saltworks) were fixed factors. Since the number of foraging individuals could be influenced by the total number of birds in the area, we included the total number of individuals of each sex as covariate. Seasonal changes in foraging activity (percentage of feeding birds), foraging time, and sex-related differences in feeding rate and intake rate were evaluated also by ANCOVA with sex, season, and site as fixed factors and 
density of birds as a covariate. Density of birds $\left(\mathrm{ha}^{-1}\right)$ was included as covariate because a study in the same intertidal zone suggested that a high density of shorebirds influences the behavior of the invertebrate prey, possibly affecting the birds' intake rate negatively (Masero and Pérez-Hurtado 2001). We assessed differences in mean diurnal and nocturnal activity with Student's $t$-test. The data were inspected for normality and homoskedasticity and were normalized by arcsine transformation if needed. When analyses showed significant differences, a post-hoc Tukey test was used. Unless stated otherwise, mean values are presented with $\pm \mathrm{SD}$, and the significance level for all tests was set at $\alpha<0.05$. All statistical analyses were performed with Statistica 7.0 (StatSoft, Inc., 2004).

\section{RESULTS}

\section{FOR AGING}

The percentage of individuals moving to the intertidal zone at low tide decreased from $88 \%$ in winter to $30 \%$ in the breeding season $\left(F_{1,25}=74.93, P<0.05\right)$. Mean foraging activity on intertidal mudflats decreased from winter to the breeding season for both sexes $\left(F_{1,24}=65.44, P<0.05\right)$, particularly for females $\left(F_{1,24}=25.20, P<0.05\right.$; Table 1$)$. This change was because females shortened their time foraging on the mudflats, during the breeding season concentrating their foraging mainly between $2 \mathrm{hr}$ before and $1 \mathrm{hr}$ after the maximum low tide (Fig. 2).

The ratio of individuals foraging at night increased from 0.37 in winter to 0.51 in the breeding season $\left(t_{6}=-7.02 P<\right.$ 0.05 ). Throughout the study period there was no nocturnal foraging in the saltworks at night.

During the breeding season females allocated less time to foraging than did males $(614.75 \pm 27.65$ and $282.28 \pm 37.11$ min day $^{-1}$ for females; $627.86 \pm 19.26$ and $405 \pm 40.54$ minutes per day for males, during the winter and breeding season, respectively; $\left.F_{1,12}=11.64, P<0.05\right)$.

\section{DIET}

Combining data from visual observations, feces collected in each habitat, and the knowledge of available prey yielded a reliable estimate of the plover's prey and their sizes. On the mudflats the main prey was the polychaete worm Nereis diversicolor, which appeared in 100\% of feces analyzed and 100\% of visual observations, supplying more than the $80 \%$ of the biomass the plovers consumed at both seasons (Fig. 3). The aquatic beetle Ochthebius sp. appeared in most feces (>70\%) at both seasons, but it supplied less than $10 \%$ of the biomass the plovers ingested (Fig. 3). The remaining prey items appeared in $<30 \%$ of feces and supplied less than $10 \%$ and $20 \%$ of the ingested biomass in winter and the breeding season, respectively (Fig. 3).

At both seasons Kentish Plovers ingested predominantly polychaetes $\sim 10 \mathrm{~cm}$ long (Fig. 4 ). We could not assess the
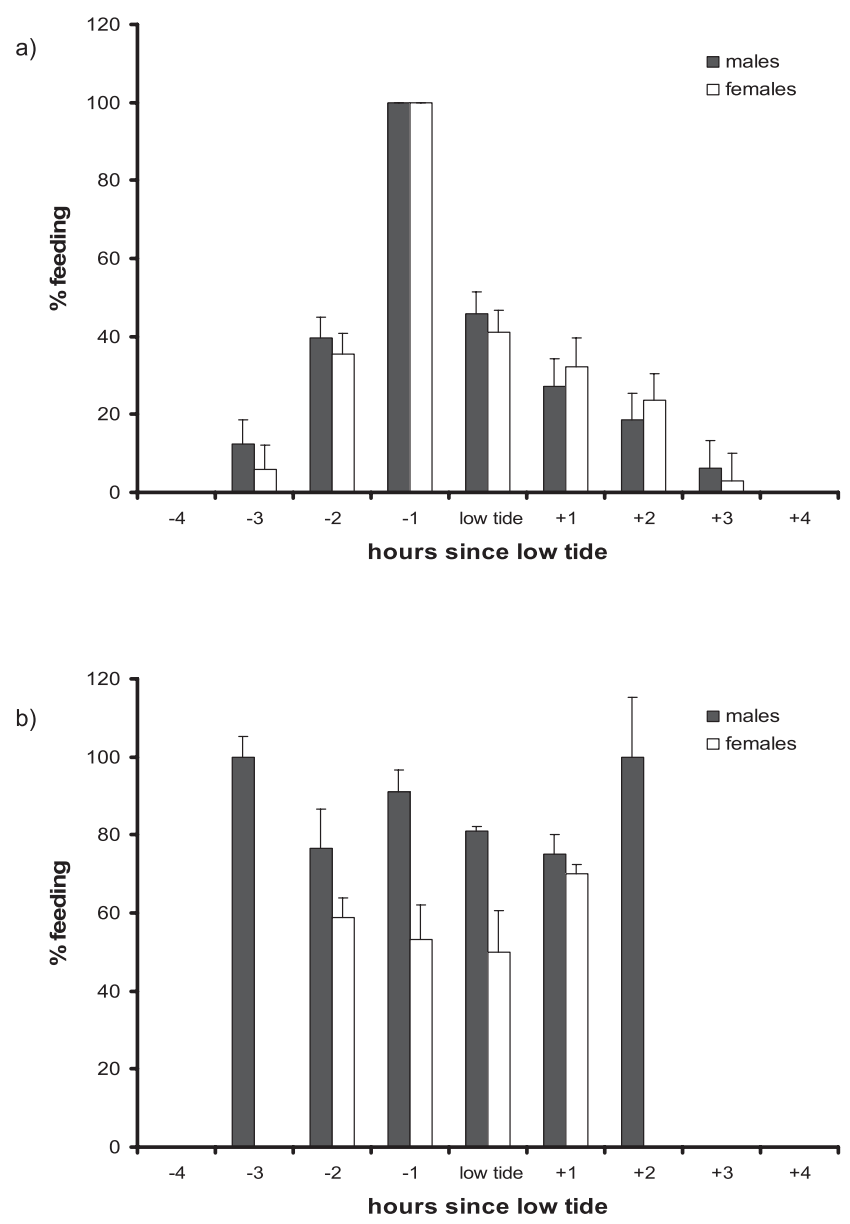

FIGURE 2. Mean hourly foraging activity of male and female Kentish Plovers during daylight on intertidal mudflats in relation to tides during the winter (a) and breeding season (b).

length of the Ochthebius beetles ingested, but the length of those available in the saltworks ranged from 1 to $3 \mathrm{~mm}$ at both seasons (Castro 2001). To calculate intake rate, we collected a random sample of 60 individuals of this beetle from the pans to calculate the average biomass per individual (mean biomass per individual: $6.6710^{-5} \mathrm{~g}$ ash-free dry mass).

\section{INTAKE RATE}

Although feeding rates were significantly higher in the saltworks than on the mudflats $\left(F_{1,164}=42.99, P<0.05\right.$, Table 2$)$, intake rates were significantly higher (around $10 \times$ higher) on the mudflats than in the saltworks $\left(F_{1,164}=70.95, P<0.05\right.$; Table 2$)$. The plovers increased their intake rate from winter to the breeding season significantly on the mudflats $\left(F_{1164}=4.45, P<0.05\right.$; Table 2$)$ but not in the saltworks $\left(F_{1,164}=0.07, P=0.79\right.$; Table 2$)$, although there were no significant differences between the sexes at either season or in either habitat $\left(F_{1,164}=0.07, P=0.79\right.$; Table 2). The density of feeding birds on the mudflats had no significant effect on intake rate $\left(F_{1,164}=0.78, P=0.38\right)$. 
a)

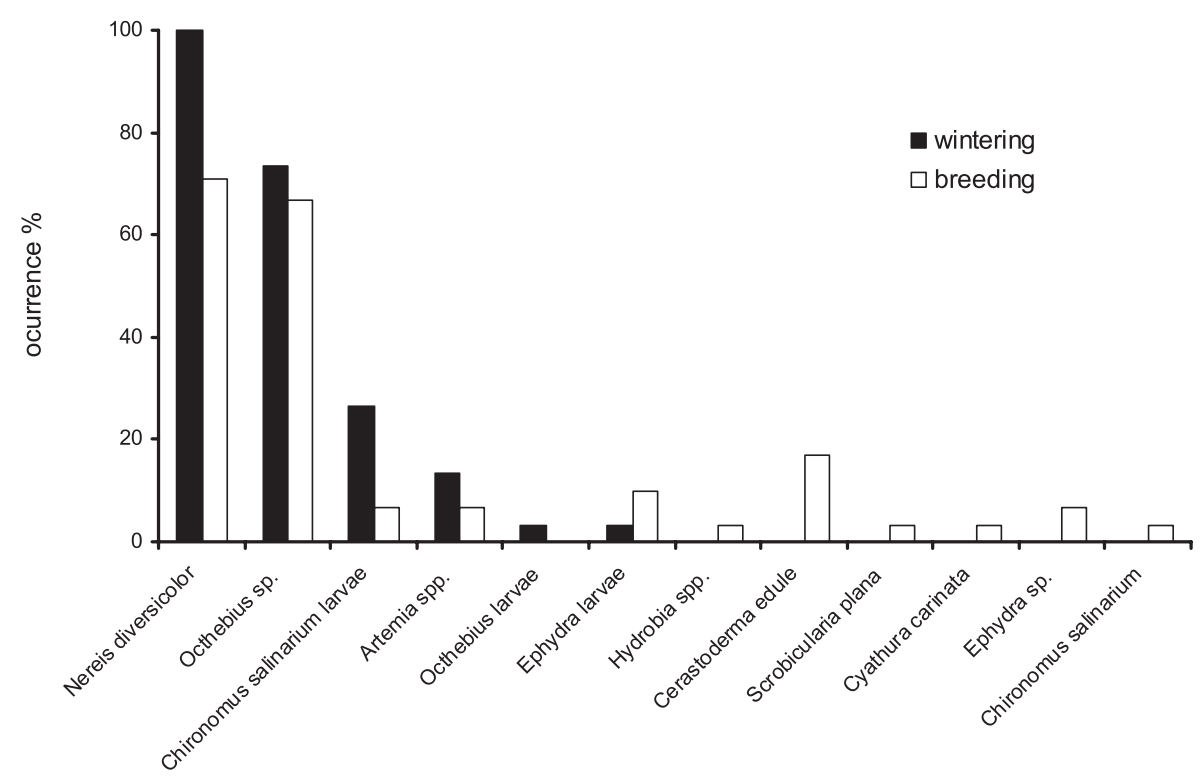

b)

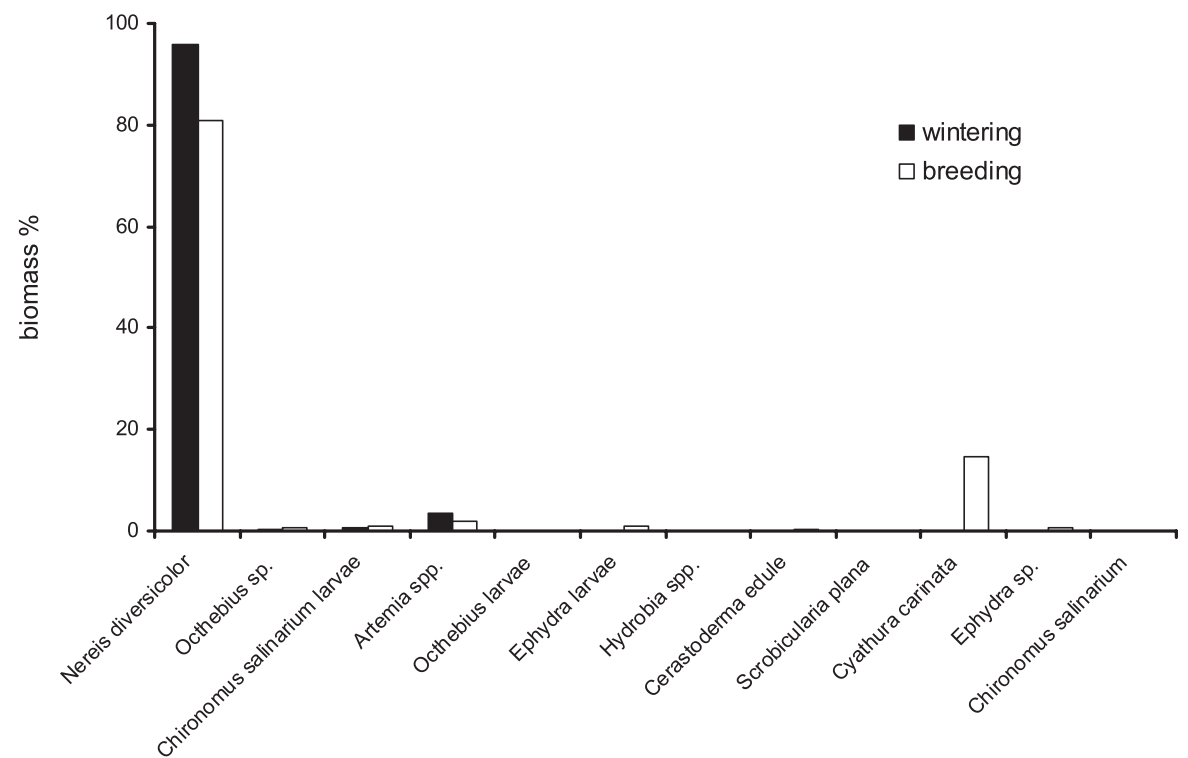

FIGURE 3. Occurrence (a) and biomass (b) of the prey recorded in the feces of Kentish Plovers during the winter $(n=32)$ and breeding season $(n=30)$.

\section{DISCUSSION}

The foraging strategy of Kentish Plovers, as measured by habitat use, intake rate, and time allocated to feeding, shifted seasonally. Both sexes increased their intake rate during the breeding season and decreased their daylight feeding time, so that the conflict of foraging on the mudflats (where the main profitable prey were available) with nesting (which necessarily takes place on the adjacent supratidal habitat) was resolved by shortening the foraging time on the mudflats and therefore minimizing time away from the nesting areas.

According to energy-maximization principles (Stephens and Krebs 1986), the saltworks were a suboptimal foraging habitat for the plovers, which obtained ten times less biomass (energy) per unit time in this habitat than on the intertidal mudflats. Indeed, according to Zwarts and Wannik's (1993) equation for assessing minimum profitable intake rate as a function of a shorebird's body mass, the plovers' intake rate 
(a)
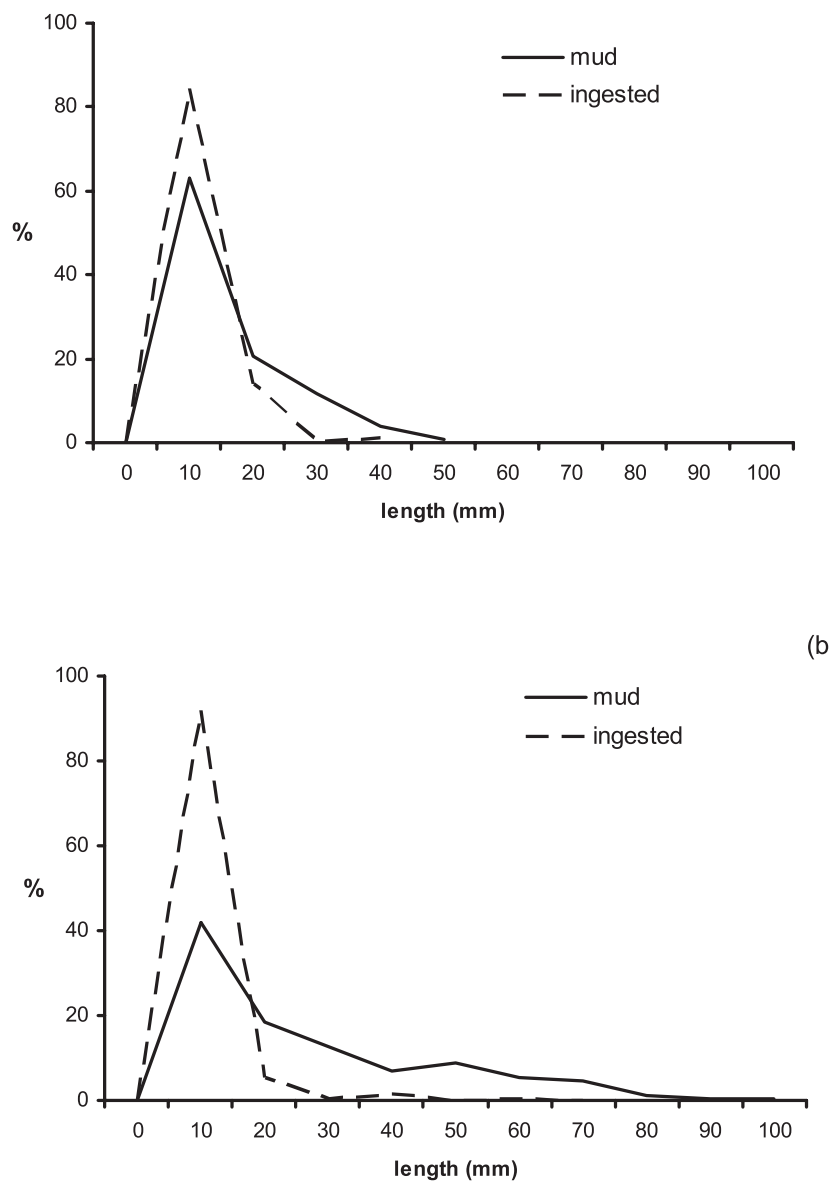

FIGURE 4. Comparison of the length classes of the ragworm Nereis diversicolor available on the intertidal mudflats (solid line) and in the feces of Kentish Plovers (broken line) during the winter(a) and breeding season (b). Data on length classes available on mudflats are from Castro (2001).

in the saltworks was only $27 \%$ of the minimum intake rate expected for it. Use of the saltworks at low tide during the breeding season increased. Because no density-dependent factors were apparently operating in the intertidal mudflats, the longer time that the birds spent in the saltworks during the breeding season was likely not due to their being displaced from the mudflats by other individuals. The results suggest that the birds remain in the saltworks during low tide because of their breeding.

By increasing their intake rates during the breeding season, the plovers obtained more energy in a shorter time than in winter, thus minimizing foraging time and increasing time available for other activities. Females allocated almost $2 \mathrm{hr}$ less to foraging during daylight in the breeding season, moving onto the mudflats for feeding just during maximum mud exposure, when, a priori, more prey are available (Esselink and Zwarts 1989). Males also decreased their feeding on the mudflats, although the decrease was not as sharp as for females.

Depending on the phase of breeding, each sex's time constraint for feeding is greater or lesser. Females incubate mainly during daylight, males mostly at night (Warriner et al. 1986, Fraga and Amat 1996, Kosztolányi and Székely 2002). The females usually desert the brood when chicks are 7-20 days old (Warriner et al. 1986, Székely and Lessells 1993, Amat et al. 1999). Therefore, during incubation females are more timeconstrained for feeding than are males, although the opposite is the case after hatching. We did not follow individual birds, and our estimates are population-based, so that females and males we studied may have been in different stages of breeding. However, we measured all variables when we found the greatest number of active nests, implying that most individuals recorded during our observations were at a similar stage.

Multiplying the daily time allocated to feeding by the intake rate, and assuming an assimilation efficiency of $80 \%$ for Nereis diversicolor (Castro et al. 2008) and 70\% for Ochthebius (Bell 1990), one can estimate the plovers' daily energy consumption. Using the equation of Nagy et al. (1999) to estimate the daily theoretical energy consumption of wild birds, one can compare the energy consumption we estimate with the theoretical value. According to our estimates, males consumed $131.42 \mathrm{~kJ} \mathrm{day}^{-1}$ and $121.58 \mathrm{~kJ}$ day $^{-1}$, females $141.02 \mathrm{~kJ}$ day $^{-1}$ and $97.98 \mathrm{~kJ} \mathrm{day}^{-1}$ during the winter and breeding season, respectively. According to the theoretical estimates, the energy

TABLE 2. Mean ( \pm 1 SD) feeding rate and intake rate of male and female Kentish Plovers foraging on the intertidal mudflats and in the adjacent saltworks during the winter and breeding season.

\begin{tabular}{llllllll}
\hline \hline & \multicolumn{3}{c}{ Intertidal mudflats } & & & \multicolumn{2}{c}{ Saltworks } \\
\cline { 2 - 3 } & Feeding rate & Intake rate & $n$ & & Feeding rate & Intake rate & $n$ \\
\hline Winter & & & & & & & \\
$\quad$ Males & $13.77 \pm 6.58$ & $0.20 \pm 0.10$ & 20 & & $19.89 \pm 4.49$ & $0.03 \pm 0.01$ & 12 \\
$\quad$ Females & $13.59 \pm 5.57$ & $0.22 \pm 0.11$ & 23 & & $23.72 \pm 5.49$ & $0.03 \pm 0.02$ & 17 \\
Breeding & & & & & & & \\
$\quad$ Males & $13.39 \pm 8.10$ & $0.33 \pm 0.20$ & 43 & & $26.54 \pm 17.28$ & $0.04 \pm 0.03$ & 18 \\
$\quad$ Females & $12.35 \pm 7.11$ & $0.34 \pm 0.31$ & 27 & & $19.09 \pm 6.91$ & $0.03 \pm 0.01$ & 13 \\
\hline
\end{tabular}


ingested should be $138.03 \mathrm{~kJ}$ day $^{-1}$ and $147.53 \mathrm{~kJ}$ day $^{-1}$ during these two periods, respectively (we used a mean body mass of $39.55 \pm 3.95$ for winter and $43.13 \pm 3.78$ for the breeding season-data from birds captured in the saltworks. In our study area the masses of males and females were similar: $t_{13}=$ $-0.83, P=0.43$, and $t_{21}=1.59, P=0.13$, for wintering and breeding birds, respectively). Females' apparently low energy consumption could be a consequence of the assumptions we made about nocturnal foraging. Following Zwarts et al. (1990), we measured nocturnal activity within $2 \mathrm{hr}$ of low tide and assumed that there were neither sex-related differences in intake rate nor differences in foraging birds' sex ratio. Nonetheless, at night, females' intake rate should be higher (Kuwae 2007) or their activity should be higher than we found in this study, with females foraging throughout the low-tide period.

Diet did not change by season, with the polychaete worm Nereis diversicolor being the plover's primary prey. Breeding is considered to be an activity with a great requirement for protein (Murphy 1994). Nereis diversicolor is a protein-rich invertebrate with a protein content $>50 \%$ (Castro et al. 2008), suggests that it provides the plover the protein it requires for breeding, so that it does not need to shift its diet during the breeding season.

The Kentish and Snowy Plovers are undergoing a sharp numerical decline in Europe and the Americas (Brown et al. 2000, Delany and Scott 2006). To the best of our knowledge, no previous studies have estimated the seasonal variation in this species' intake rates. Our results indicate that, for realistic assessments of prey acquisition, energy budgets, or habitat quality, the species' conservation plans should take into account these variations in intake rates.

\section{ACKNOWLEDGMENTS}

We are grateful to Gonzalo Muñoz and S. Marin for their field assistance and to Isabel Torija and Angeles Muñoz for their help with identifying invertebrates. We also thank the staff of the environmental office of Cádiz Bay Natural Park for facilitating all the permissions and the company Unión Salinera for allowing us to study at the Salinas La Tapa.

\section{LITERATURE CITED}

Amat, J. A., R. M. Fraga, And G. M. Arroyo. 1999. Brood desertion and polygamous breeding in the Kentish Plover Charadrius alexandrinus. Ibis 141:596-607.

Amat, J. A.,G. H. Visser, A. Pérez-Hurtado, and G. M. Arroyo. 2000. Brood desertion by female shorebirds: a test of the differential parental capacity hypothesis on Kentish Plovers. Proceedings of the Royal Society of London B 267:2171-2176.

Amat, J. A., AND J. A. MASERo. 2007. The functions of belly-soaking in Kentish Plover Charadrius alexandrinus. Ibis 149:91-97.

BELL, G. P. 1990. Birds and mammals on an insect diet: a primer on diet composition analysis in relation to ecological energetics. Studies in Avian Biology 13:416-423.

Brown, S., C. Hickey, B. Gill, L. Gorman, C. Gratto-Trevor, S. Haig, B. Harrington, C. Hunter, G. Morrison, G. Page, P. Sanzenbacher, S. Skagen, And N. WARnock. 2000. National shorebird conservation assessment: shorebird conservation status, conservation units, population estimates, population targets, and species priorization. Manomet Centre for Conservation Sciences. <http://www.Manomet.org/programs/shorebirds> (10 April 2009).

CAstro, M. 2001. Ecología de la alimentación del Chorlitejo Patinegro Charadrius alexandrinus: existe plasticidad comportamental o fisiológica asociada al sexo?. Ph.D. dissertation, University of Cádiz, Cádiz, Spain.

Castro, M., J. A. Masero, C. Megina, J. A. Amat, And A. PéREZ-HuRTADO. 2008. Energy and macronutrient assimilation efficiencies of Snowy Plover (Charadrius alexandrinus) feeding on the polychaete ragworm (Nereis diversicolor). Auk 125: 368-373.

Cuthill, I. C., And A. I. Houston. 1997. Managing time and energy, p. 97-120. In J. R. Krebs and N. B. Davies [EDS.], Behavioural ecology: an evolutionary approach, 4th ed. Blackwell Science, Oxford, UK.

Delany, S., AND Scott, D. [EDS.]. 2006. Waterbird population estimates, 4th ed. Wetlands International, Wageningen, the Netherlands.

Durrell, S. E. A. LE V. Dit. 2001. Individual feeding specialisation in shorebirds: population consequences and conservation implications. Biological Reviews 75:503-518.

EsSELINK, P., AND L. ZWARTS. 1989. Seasonal trend in burrow depth and tidal variation in feeding activity of Nereis diversicolor. Marine Ecology Progress Series 56: 243-254.

FraGA, R. M., AND J. A. AmAT. 1996. Breeding biology of a Kentish Plover (Charadrius alexandrinus) population in an inland saline lake. Ardeola 43:69-85.

Goss-Custard, J. D., A. D. West, M. G. Yates, R. W. G. CalDow, R. A. Stillman, L. Bardsley, J. Castilla, M. Castro, V. Dierschke, S. E. A. Le V. dit Durell, G. EichHorn, B. J. Ens, K. M. Exo, P. U. Udayangani-Fernando, P. N. Ferns, P. A. R. Hockey, J. A. Gill, I. Johnstone, B. Kalejta-Summers, J. A. Masero, F. Moreira, R. V. Nagarajan, I. P. F. Owens, C. Pacheco, A. Pérez-Hurtado, D. Rogers, G. Scheiffarth, H. Sitters, W. J. Sutherland, P. Triplet, D. H. Worrall, Y. Zharikov, L. Zwarts, and R. A. Pettifor. 2006. Intake rates and the functional response in shorebirds (Charadriiformes) eating macro-invertebrates. Biological Reviews 81:1-29.

Hayman, P., J. Marchant, And T. Prater. 1995. Shorebirds: an identification guide to the waders of the world. A. \& C. Black, London.

HoRTAS, F. 1997. Evolución de las comunidades de aves limícolas (Orden Charadriiformes) en salinas del suroeste de España. Estructura espacio-temporal de las poblaciones y uso del hábitat. Ph.D. dissertation, Universidad de Cádiz, Cádiz, Spain.

Hurlbert, S.H. 1984. Pseudoreplication and design of ecological field experiments. Ecological Monographs 54:187-211.

Kosztolányi, A., And T. SzÉKely. 2002. Using a transponder system to monitor incubation routines in Snowy Plovers. Journal of Field Ornithology 73:199-205.

KuwAE, T. 2007. Diurnal and nocturnal feeding rate in Kentish Plovers Charadrius alexandrinus on an intertidal flat as recorded by telescopic video systems. Marine Biology 151:663-673.

LAFFERTY, K. D., D. GoOdMAn, AND C. SANDOVAL. 2006. Restoration of breeding by Snowy Plovers following protection from disturbance. Biodiversity and Conservation 15:2217-2230.

Masero, J. A., M. Pérez-GonzÁlez, M. Basadre, and M. OteroSAAVEDRA. 1999. Food supply for waders (Aves: Charadrii) in an estuarine area of the Bay of Cádiz (SW Iberian Peninsula). Acta Oecologica 20:429-434. 
Masero, J. A., A. Pérez-Huratdo, M. Castro, and G. M. Arroyo. 2000. Complementary use of intertidal mudflats and adjacent salinas by foraging waders. Ardea 88:177-191.

Masero, J. A., AND A. PÉrez-Hurtado. 2001. Importance of the supradital habitats for maintaining overwintering shorebird populations: how Redshanks use tidal mudflats and adjacent saltworks in southern Europe. Condor 103:21-30.

Masero, J. A., S. M. Estrella, And J. M. SÁnChez-Guzman. 2007. Behavioural plasticity in foraging mode of typical plovers. Ardea 95:259-265.

MurPHY, M. E. 1994. Dietary complementation by wild birds: considerations for field studies. Journal of. Bioscience 19:355-368.

Nagy, K. A., I. A. Girard, And T. K. Brown. 1999. Energetics of free-ranging mammals, reptiles, and birds. Annual Review of Nutrition. 19:247-277.

Pérez-Hurtado, A., M. I. Gil, M. Castro, G. M. Arroyo, And J. A. MAsero. 1994. Estudio comparativo de parámetros reproductivos del Chorlitejo Patinegro, Charadrius alexandrinus, en salinas y cultivos piscícolas del parque natural de la Bahía de Cádiz. XII Spanish Congress of Ornithology, Almería, Spain.

Piersma, T. 1996. Family Charadriidae (plovers), p. 384-442. In J. del Hoyo, A. Elliott, and J. Sargatal [EDS.], Handbook of the Birds of the World, vol. 3: Hoatzin to Auks. Lynx Edicions, Barcelona, Spain.

Sibly, R. M., AND P. CALOW [EDS.]. 1986. Physiological ecology of animals: an evolutionary approach. Blackwell Scientific, Oxford, UK.

Sillet, T. S., R. T. Holmes, And T. W. Sherry. 2000. Impacts of a global climate cycle on population dynamics of a migratory songbird. Science 288:2040-2042.

SKAGEN, S. K. 2006. Migration of stopovers and the conservation of arctic-breeding calidridine sandpipers. Auk 123:313-322.

StATSOFT, Inc. 2004. Statistica, release 7.0. Statsoft, Inc., Tulsa, OK.
Stephens, D. W., and J. R. Krebs [eds.] 1986. Foraging theory. Princeton University Press, Princeton, NJ.

SzÉKely, T., AND C. M. LESSELlS. 1993. Mate changes by Kentish Plover Charadrius alexandrinus. Ornis Scandinavica 24:317-322.

ToRIJA, I. E. 2005. Ecología de la alimentación en los pollos de Chorlitejo patinegro Charadrius alexandrinus: efecto de los requerimientos nutricionales e implicación en la conservación y manejo de hábitats. M.Sc. thesis. Universidad de Cádiz, Cádiz, Spain.

TulP, I., AND H. SHEKKERMAN. 2006. Time allocation between feeding and incubation in uniparental arctic-breeding shorebirds: energy reserves provide leeway in a tight schedule. Journal of Avian Biology 37:207-218.

Warriner, J. S., J. C. Warriner, G. W. Page, and L. E. Stenzel. 1986. Mating system and reproductive success of small populations of polygamous Snowy Plovers. Wilson Bulletin 98:15-37.

WEBB, D. R. 1987. Thermal tolerance of avian embryos: a review. Condor 89:874-898.

Williams, T. D. 1996. Variation in reproductive effort in female Zebra Finches (Taeniopygia guttata) in relation to nutrient-specific dietary supplements during egg laying. Physiological Zoology 69:1255-1275.

ZwARTS, L., A.-M. Blomert, AND R. HuPKES. 1990. Increase of feeding time in waders preparing for spring migration from Banc d'Arguin, Mauritania. Ardea 78:237-256.

ZwArts, L., AND A.-M. BlomerT. 1992. Why Knot Calidris canutus take medium-sized Macoma balthica when six prey species are available. Marine Ecology Progress Series 83:113-128.

ZWARTS, L., AND J. H. WANINK. 1993. How the food supply harvestable by waders in the Wadden Sea depends on the variation in energy density, body weight, biomass, burying depth and behaviour of tidal-flat invertebrates. Netherlands Journal of Sea Research 31:441-476. 